\title{
Phytochemical Analysis of Hybanthus enneaspermus using UV, FTIR and GC- MS
}

\author{
T. Anand ${ }^{1 *}$, K.Gokulakrishnan ${ }^{2}$ \\ ${ }^{I}$ Department of Biochemistry PRIST University, Vallam, Thanjavur 613 403, Tamil Nadu, India \\ ${ }^{2}$ Department of chemistry PRIST University, Vallam, Thanjavur 613 403, Tamil Nadu, India
}

\begin{abstract}
The present study was carried out to characterize the bioactive constituents present in ethanolic extracts of Hybanthus enneaspermus using UV, FTIR and GC-MS. The crude extracts were scanned in the wavelength ranging from 300-1100 nm by using Perkin Elmer Spectrophotometer and the characteristic peaks were detected. For GC-MS analysis, 20 g sample is extracted with $50 \mathrm{ml}$ ethanol, filtered in ash less filter paper with $4 \mathrm{~g}$ sodium sulphate and the extract is concentrated to $1 \mathrm{ml}$ by bubbling nitrogen into the solution. The compound detection employed the NIST Ver. 2.0 - Year 2005 library. The biological activities are based on Dr. Duke's Phytochemical and Ethnobotanical Databases by Dr. Jim Duke of the Agricultural Research Service/USDA. The UV profile showed different peaks ranging from 300-1100 nm with different absorption respectively. The FTIR spectrum confirmed the presence of phenols, alcohols, alkanes, alkyl halides, carboxylic acids, aromatics, nitro compounds and amines in ethanolic extract. The results of the GC-MS analysis provide different peaks determining the presence of phytochemical compounds with different therapeutic activities. The major phytoconstituents were (5E,13E)-5,13-Docosadienoic acid (20.90\%) and Cedran-diol, 8S, 14- (13.02) which are possessing many biological activities. hence this study creates a platform to screen many bioactive components to treat many diseases.
\end{abstract}

Keywords: FTIR, GC-MS, Hybanthus enneaspermus , Phytochemical, UV-spectrometry

\section{INTRODUCTION}

In order to overcome health problems, the tribes of developing countries primarily rely on herbal medicines which are giving beneficial effect to humans [1]. The herbs are constantly being screened for their biological and pharmacological activities such as anti-diabetic, anti-oxidant, anti-microbial, laxative, and anti-cancer activities [2-7]. The herbs are having numerous bio active components which are identified (at less than $1 \mathrm{ng}$ ) by using GC or LC-MS. Spectroscopic (UV-Vis, FTIR) methods together or separate can be used because of its simplecity, cost-effective and rapid tests for detecting phytocomponents. [8-10] Hybanthus enneaspermus (Linn) F. Mull is a violaceae family known as Sthalakamala in ayurveda which is distributed in the tropical and sub tropical regions in the world. It is a woody troches herb present in warmer parts of India. It grows $15-30 \mathrm{~cm}$ in height with ascending nature [11]. The plant possesses anti-convulsant [12,13], and also used to treat diarrhea, dysuria, urinary tract infections, male sterility and diabetes because which possess many bioactive components such as phenol,alkaloids and flavanoids[14,15]. In some part of India the plant is used to treat diabetes and which is also having anti-oxidant property and free radical scavenging activity [16].

\section{Materials and Methods}

\subsection{Plant material and preparation of extract}

Whole plants of H. enneaspermus were collected in the month of November and December from PRIST University Campus, Thanjavur, Tamil Nadu, India. The collected plants were open-air-dried under the shade, pulverized in to a moderately coarse powder (using pestle and mortar). Three-hundred grams $(300 \mathrm{~g})$ of the powered plants were extracted with ethanol (70\%) using soxhlet apparatus for $48 \mathrm{~h}$. A semi-solid extract was obtained after complete elimination of alcohol under reduced pressure. The extract was stored in refrigerator until used. The extract contains both polar and non-polar phytocomponents.

\subsection{UV and FTIR Spectroscopic analysis}

The extracts were examined under visible and UV light for proximate analysis. For UV and FTIR spectrophotometer analysis, the extracts were centrifuged at $3000 \mathrm{rpm}$ for $10 \mathrm{~min}$ and filtered through Whatmann No. 1 filter paper by using high pressure vacuum pump. The sample is diluted to 1:10 with the same solvent. The extracts were scanned in the wavelength ranging from 300-1100 nm using Perkin Elmer Spectrophotometer and the characteristic peaks were detected. FTIR analysis was performed using Perkin Elmer Spectrophotometer system, which was used to detect the characteristic peaks and their functional groups. The peak values of the UV and FTIR were recorded. Each and every analysis was repeated twice for the spectrum confirmation. 


\subsection{GC-MS analysis}

GC-MS analysis was carried out on a GC clarus 500 Perkin Elmer system comprising a AOC-20i autosampler and gas chromatograph interfaced to a mass spectrometer (GC-MS) instrument employing the following conditions: column Elite-1 fused silica capillary column (30 x $0.25 \mathrm{~mm}$ ID x $1 \mu \mathrm{M} \mathrm{df}$, composed of $100 \%$ dimethyl poly diloxane), operating in electron impact mode at $70 \mathrm{eV}$; helium (99.999\%) was used as carrier gas at a constant flow of $1 \mathrm{ml} / \mathrm{min}$ and an injection volume of $0.5 \mu \mathrm{I}$ was employed (split ratio of 10:1) injector temperature $250{ }^{\circ} \mathrm{C}$; ion-source temperature $280{ }^{\circ} \mathrm{C}$. The oven temperature was programmed from $110^{\circ} \mathrm{C}$ (isothermal for $2 \mathrm{~min}$ ), with an increase of $10{ }^{\circ} \mathrm{C} / \mathrm{min}$, to $200^{\circ} \mathrm{C}$, then $5^{\circ} \mathrm{C} / \mathrm{min}$ to $280^{\circ} \mathrm{C}$, ending with a $9 \mathrm{~min}$ isothermal at $280^{\circ} \mathrm{C}$. Mass spectra were taken at $70 \mathrm{eV}$; a scan interval of 0.5 seconds and fragments from 40 to $450 \mathrm{Da}$. Total GC running time was $36 \mathrm{~min}$.

\subsection{Identification of components}

The relative percentage amount of each component was calculated by comparing its average peak area to the total areas. The detection employed the NIST (National Institute of Standards and Technology) Ver.2.0-Year 2005 library. The compound prediction is based on Dr. Duke's Phytochemical and Ethnobotanical Databases by Dr. Jim Duke of the Agricultural Research Service/USDA. Interpretation of GC-MS was conducted using the database of NIST having more than 62,000 patterns. The spectrum of the unknown component was compared with the spectrum of the known components stored in the NIST library. The name and molecular weight of the components of the test materials were ascertained.

\section{RESULTS AND DISCUSSION}

The qualitative UV spectrum profile of Hybanthus enneaspermus L. ethanolic extract was selected at wavelength

from 300 to $1100 \mathrm{~nm}$ due to sharpness of the peaks and proper baseline. The UV profile of ethanol extract of Hybanthus enneaspermus chosen wavelength of 300 to $400 \mathrm{~nm}$ and the profile showed the peaks at 338 and 365 respectively and another chosen wavelength of 900 to 1100 showed the peaks at 922 and 1042.(Fig.1).

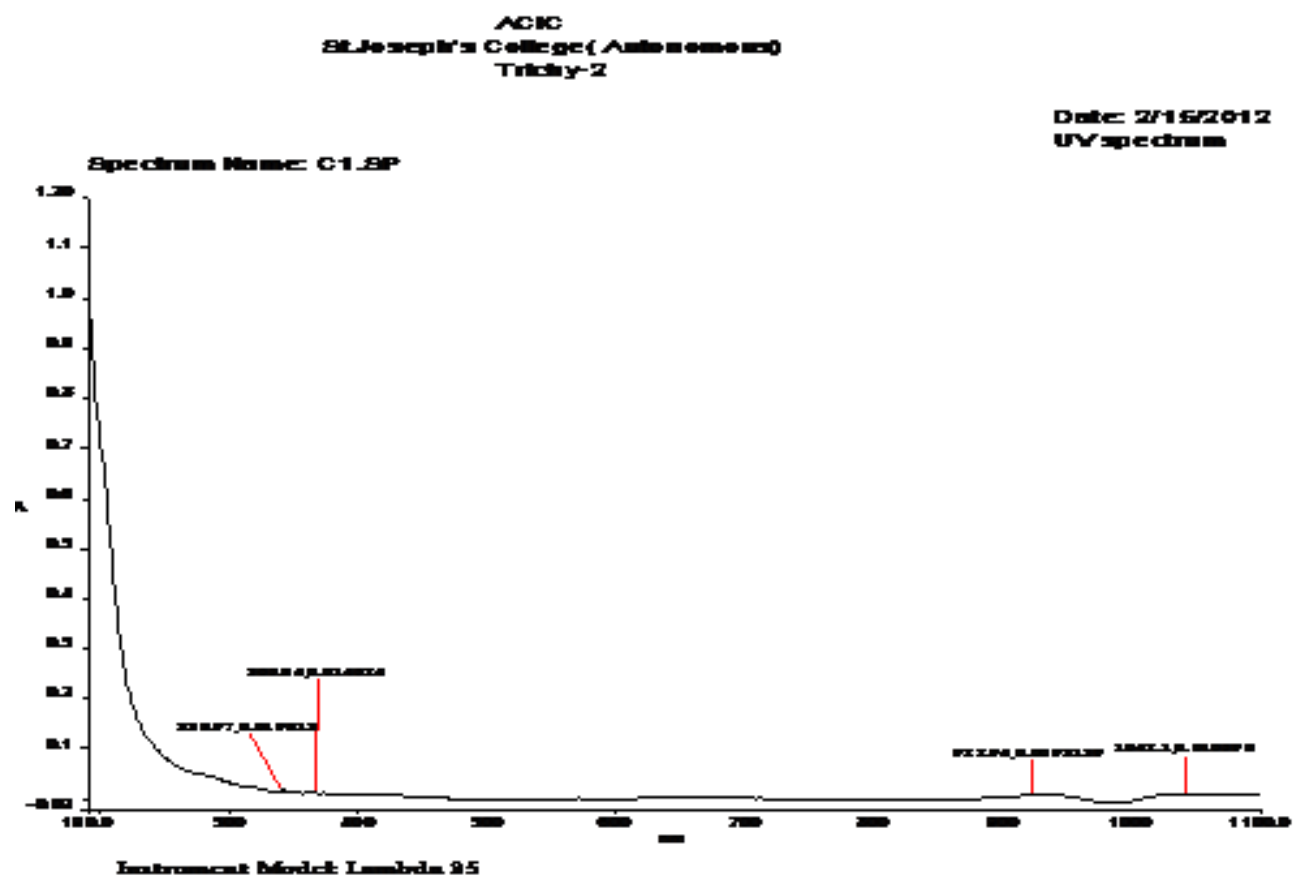

Figure 1: UV spectrum of ethanolic extract of Hybanthus enneaspermus

The FTIR spectrum was used to identify the functional group of the active components based on the peak value in the region of infrared radiation. The results of FTIR peak values and functional groups were represented in Table 1 . The FTIR spectrum profile was illustrated in the Fig. 2. FTIR spectrum confirmed the presence of alcohols, phenols, alkanes, alkynes, alkyl halides, aldehydes, carboxylic acids, aromatics, nitro compounds and amines in ethanol extract. Hence, the 
IOSR Journal of Pharmacy

Vol. 2, Issue 3, May-June, 2012, PP.520-524

crude extracts subjected to UVand FTIR analysis is used for the identification of chemical constituents present in Hybanthus enneaspermus. In addition, UV and FTIR spectroscopy is proved to be a reliable and sensitive method for detection of biomolecular composition.

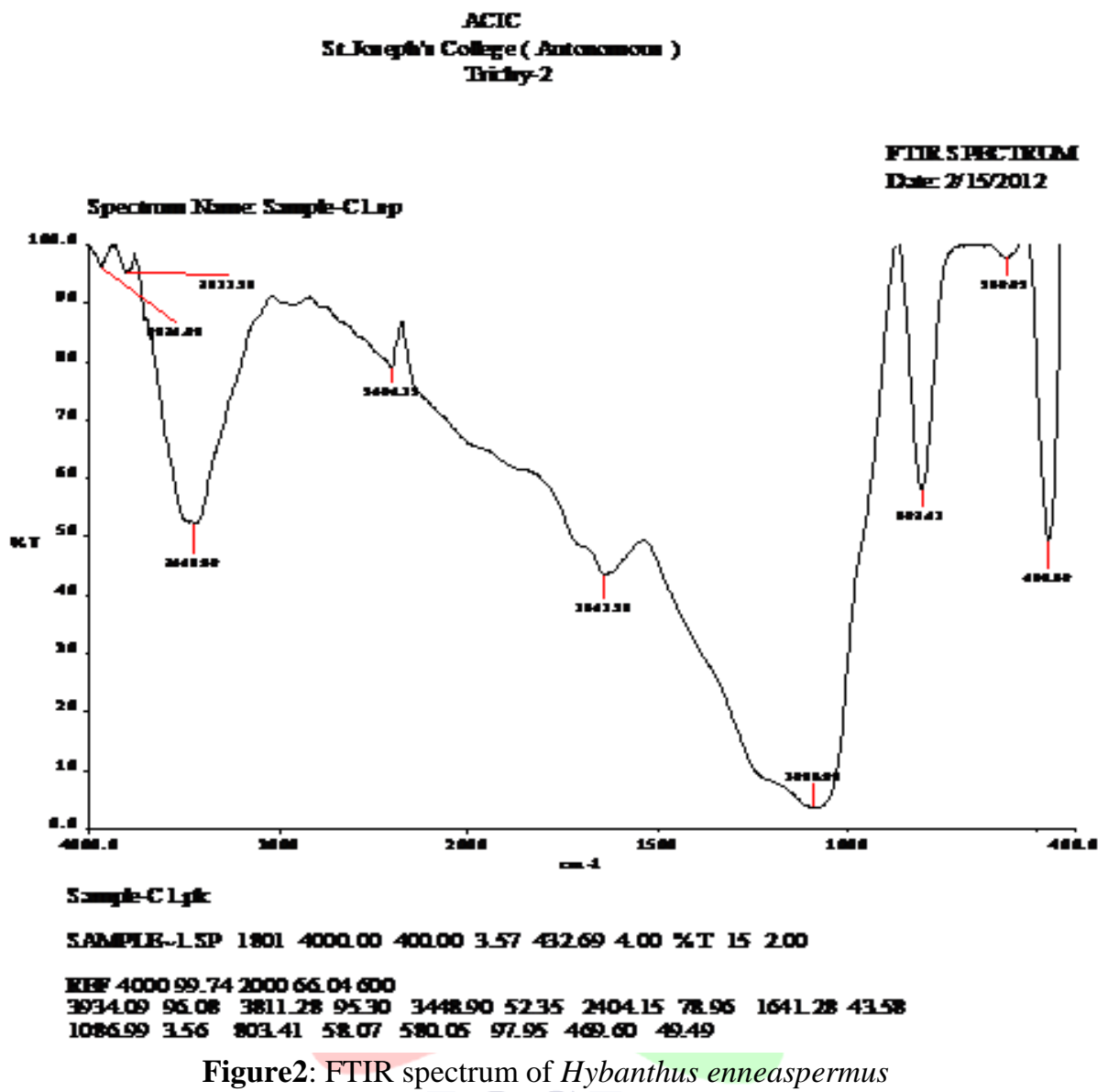

Table 1: FTIR peak values and functional groups of different extracts of Hybanthus enneaspermus.

\begin{tabular}{|l|l|}
\hline Peak values & Functional groups \\
\hline 3934 & Unknown \\
\hline 3811 & Unknown \\
\hline 3448 & Alcohol (including phenol) \\
\hline 2404 & Carboxylic acid \\
\hline 1641 & Non-acid carbonyl \\
\hline 1086 & Alcohol \\
\hline 803 & Aromatic \\
\hline 580 & Alkyl halides \\
\hline 469 & Alkyl halides \\
\hline
\end{tabular}

The ethanolic extract of $H$. ennespearmus was subjected to GC-MS analysis. Interpretation on mass spectrum GC-MS was conducted using the database of National Institute Standard and Technology (NIST) which is having more than 62,000 patterns. The name, molecular weight and structure of the components of the test materials were ascertained. GC-MS results shown that at least 10 compounds were present in ethanolic extraction of H. ennespermus (Fig. 3 and Table 2). 


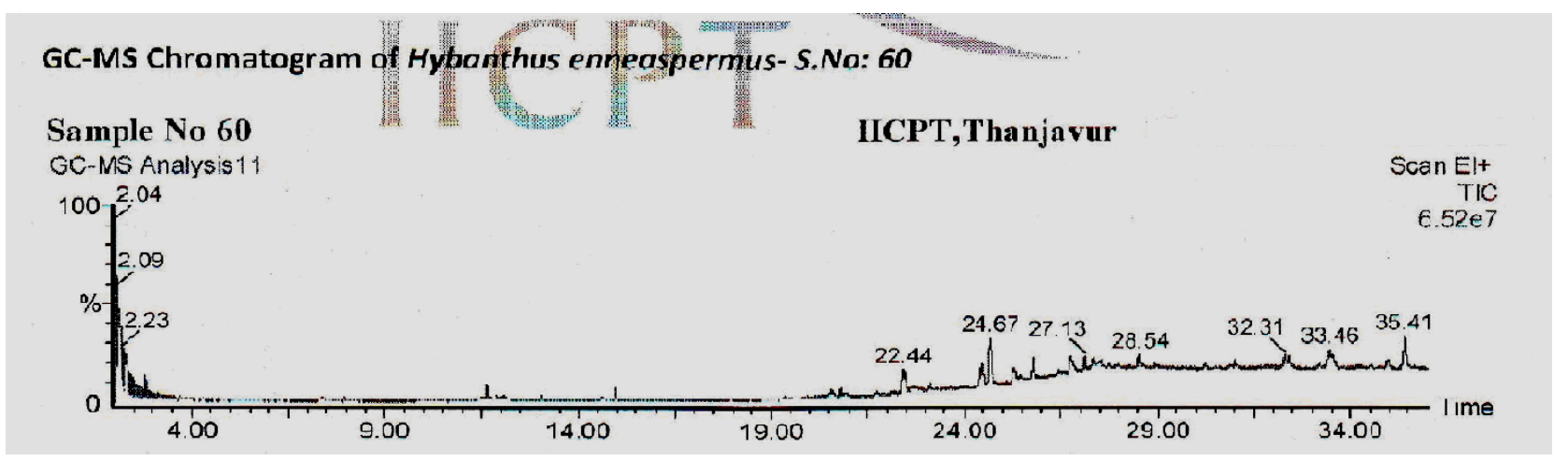

Figure 3: GC-MS of Hybanthus enneaspermus

The compounds of $H$. ennespermus was identified through mass spectrometry attached with gas chromatography. The unknown spectrum components were compared with the known spectrum components which are stored in the NIST library and the data is given Table 2.The results pertaining to GC-MS analysis leads to the identification of number of compounds from the GC fractions of the ethanolic extract of Hybanthus enneaspermus.

Table 2: phytochemical analysis of ethanolic extract of Hybanthus enneaspermus.

\begin{tabular}{|c|c|c|c|c|c|c|}
\hline RT & Name of the compound & $\begin{array}{l}\text { Molecular } \\
\text { formula }\end{array}$ & MW & $\begin{array}{l}\text { Peak } \\
\text { area } \%\end{array}$ & $\begin{array}{l}\text { Compound } \\
\text { nature }\end{array}$ & $\begin{array}{l}\text { Biological } \\
\text { activity }\end{array}$ \\
\hline 2.81 & Propane,1,1,3-triethoxy- & $\mathrm{C}_{9} \mathrm{H}_{20} \mathrm{O}_{3}$ & 176 & 6.11 & $\begin{array}{l}\text { Ether } \\
\text { compound }\end{array}$ & No activity \\
\hline 7.94 & $\begin{array}{l}\text { Phenol,4,6-di(1,1-dimethyl)-2- } \\
\text { methyl- }\end{array}$ & $\mathrm{C}_{15} \mathrm{H}_{24} \mathrm{O}$ & 220 & 0.64 & $\begin{array}{l}\text { compounds are } \\
\text { soluble and } \\
\text { chiral nature }\end{array}$ & $\begin{array}{l}\text { inhibit } \\
\text { bacterial, } \\
\text { fungal, } \\
\text { protozoan and } \\
\text { parasite growth }\end{array}$ \\
\hline 11.62 & 1,14-Tetradecanediol & $\mathrm{C}_{14} \mathrm{H}_{30} \mathrm{O}_{2}$ & 230 & 5.76 & $\begin{array}{l}\text { Alcoholic } \\
\text { compound }\end{array}$ & Antimicrobial \\
\hline 14.94 & Phytol & $\mathrm{C}_{20} \mathrm{H}_{40} \mathrm{O}$ & 296 & 2.41 & Diterpene & $\begin{array}{l}\text { Antimicrobial, } \\
\text { Anti cancer, } \\
\text { Anti- } \\
\text { inflammatory, } \\
\text { Hepatoprotecti } \\
\text { ve, Anti } \\
\text { androgenic }\end{array}$ \\
\hline 21.73 & $\begin{array}{l}\text { 2-Pepridionne, } \quad \mathrm{N}-[4-\text { bromo-n- } \\
\text { butyl]- }\end{array}$ & $\mathrm{C}_{9} \mathrm{H}_{16} \mathrm{BrNO}$ & 233 & 2.41 & Alkaloid & $\begin{array}{l}\text { Antimicrobial } \\
\text { Anti- } \\
\text { inflammatory } \\
\text { Antioxidant }\end{array}$ \\
\hline 22.44 & Cedran-diol, 8S, 14- & $\mathrm{C}_{15} \mathrm{H}_{26} \mathrm{O}_{2}$ & 238 & 13.02 & $\begin{array}{l}\text { Sesquiterpene } \\
\text { alcohol }\end{array}$ & $\begin{array}{l}\text { Antimicrobial } \\
\text { Antiinflammat } \\
\text { ory }\end{array}$ \\
\hline 24.67 & $\begin{array}{l}\text { 2H-Pyran, } \\
\text { heptadecynyloxy)tetrahydro- }\end{array}$ & $\mathrm{C}_{22} \mathrm{H}_{40} \mathrm{O}_{2}$ & 336 & 20.90 & $\begin{array}{l}\text { Flavonoid } \\
\text { fraction }\end{array}$ & $\begin{array}{l}\text { Antimicrobial } \\
\text { Antiinflammat } \\
\text { ory } \\
\text { Antioxidant }\end{array}$ \\
\hline
\end{tabular}

\section{CONCLUSION}

The investigation concluded that the stronger extraction capacity of ethanol could have been produced number of active constituents responsible for many biological activities. So that those might be utilized for the development of 
traditional medicines and further investigation needs to elute novel active compounds from the medicinal plants which may be created a new way to treat many incurable diseases.

\section{ACKNOWLEDGEMENT}

The authors are thankful to PRIST University, Thanjavur, Tamilnadu, India for their financial and excellent technical support.

\section{REFERENCES:}

[1] S.A. Dahanukar, et al., Indian J Pharmacol,32, 2000, S81-S118.

[2] W.C. Evans, Trease and Evan's pharmacognosy, 14th ed. UK: W.B. Saunders Company Limited, 1997, p.3.

[3] S. Anbuselvi, L. Jeyanthi Rebecca, M. Sathish Kumar and T. Senthilvelan, GC-MS study of phytochemicals in black gram using two different organic manures, Journal of Chemical and Pharmaceutical Research, 4(2) 2012, 1246-1250

[4] E.A. Makky, M. Mashitah, Yusoff, M.M. Ibrahim, Impact of Medicinal Plants Phytocomponents against Antibiotic Resistant Bacteria, Journal of Chemical and Pharmaceutical Research, 4(1), 2012, 881-893

[5] R. Kavitha, P. Kamalakannan, T. Deepa, R. Elamathi, S. Sridhar, J. Suresh Kumar, In vitro Antimicrobial Activity and Phytochemical Analysis of Indian Medicinal Plant Couroupita guianensis Aubl, Journal of Chemical and Pharmaceutical Research 3(6) 2011,115-121

[6] B. Meurer-Grimes, D.L. Mcbeth, B. Hallihan, S. Delph. Antimicrobial activity in medicinal plants of the Scrophulariaceae and Acanthaceae, International Journal of Pharmacognosy, 34, 1996,243-248.

[7] S. Koduru, D.S. Grierson, A.J. Afolayan. Antimicrobial activity of Solanum aculeastrum, Pharmaceutical Biology, 44, 2006,283-286.

[8] D.C. Liebler, J.A. Burr, L. Philips, A.J.L .Ham, Gas chromatography - mass spectrometry analysis of vitamin E and its oxidation products, Analytical Biochemistry, 236, 1996, 27-34.

[9] P. Aysal, A.D. Ambrus, S.J. Lehotay, A. Cannavan. Validation of an efficient method for the determination of pesticide residues in fruits and vegetables using ethyl acetate for extraction, Journal of Environmental Science Health, 42, 2007, 481-490.

[10] M.Ibrahim, M. Abd-El-Aal, Spectroscopic study of Heavy MetalsInteraction with Organic Acid, International Journal of Environment and Pollution, 35(1), 2008, 99-110.

[11] M. Ibrahim, A.J. Hameed, A. Jalbout. Molecular Spectroscopic Studyof River Nile Sediment in the Greater Cairo Region, Applied Spectroscopy, 62(3), 2008, 306-311.

[12] K.R. Kirtikar, B.D. Basu, In: Indian medicinal plants, vol. I, 2nd ed. (Delhi: Periodical Experts Book Agency, 1991) 212-213.

[13] S.Hemalatha, A.K. Wahi, P.N. Singh, J.P.N. Chansouria , Anticonvulsant and free radical scavenging activity of Hybanthus enneaspermus: A preliminary screening, Indian Journal Traditional Knowledge 2(4) 2003, 389.

[14] S.N. Yoganarasimhan, In: Medicinal plants of India - Tamilnadu, vol. II. (Bangalore: Cyber Media, 2000). p. 276.

[15] D.K. Patel, R. Kumar, S.K. Prasad, K. Sairam, S. Hemalatha, Antidiabetic and in vitro antioxidant potential of Hybanthus enneaspermus (Linn) F. Muell in streptozotocin-induced diabetic rats, Asian Pacific Journal of Tropical Biomedicine , 1, 2011m, 316-322.

[16] S. Das, S.K. Dash, S.N. Padhy, Ethno botanical information from Orissa state, India: a review, Journal of Human Ecology, 14, 2004,165-227. 